\title{
PENETAPAN AWAL BULAN DENGAN METODE ITTIHADUL MATHLA' DI INDONESIA
}

\author{
Nurul Badriyah dan Faisal \\ Dosen Hukum Islam Fakultas Syariah IAIN Langsa
}

\begin{abstract}
Determination of the beginning of the month of qamariyah in Indonesia uses several methods, namely ru'yah and hisab. In addition to these methods, to determine the entry of the beginning of the month is also marked by the appearance of hilal in a place (mathla) which is the main key in determining the beginning of the month of qamariyah. Indonesia is one of the majority Muslim countries, and in this case Indonesia is still experiencing differences in worship in that month. The difference between the beginning and end of fasting in Islamic countries is only one portrait of the condition of Muslims. Although they are one ummah, but in a concrete way the Muslims are divided. Apart from being influenced by the method, it is also influenced by differences in mathla' appearance of the moon. Ittuhâdul mathla' method can be used in determining the beginning of the month of qamariyah in Indonesia for the benefit of Muslim societies.
\end{abstract}

Keywords: Qamariyah, Ittuhâdul mathla', ru'yah

\begin{abstract}
Abstrak. Penentuan awal bulan qamariyah di Indonesia menggunakan beberapa metode, yaitu ru'yah dan hisab. Selain metode tersebut, untuk menentukan masuknya awal bulan juga ditandai dengan munculnya hilal disuatu tempat (mathla') yang merupakan kunci utama penentuan awal bulan qamariyah ini. Indonesia merupakan salah satu negara yang mayoritas penduduknya muslim, dan dalam hal ini Indonesia masih mengalami perbedaan dalam melaksanakan ibadah di bulan tersebut. Perbedaan awal dan akhir puasa di negeri-negeri Islam hanya merupakan salah satu potret keadaan kaum Muslim. Kendati mereka satu ummat, namun secara kongkrit umat Islam terpecah-pecah. Hal ini selain dipengaruhi oleh metode, juga dipengaruhi karena perbedaan mathla' munculnya bulan. Metode ittuhâdul mathla' dapat digunakan dalam penentuan awal bulan qamariyah di Indonesia untuk kemashlahatan masyarakat muslim.
\end{abstract}

Kata kunci: Qamariyah, Ittuhâdul mathla', ru'yah

\section{Pendahuluan}

Menentukan awal bulan qamariyah sangat penting artinya bagi segenap umat Islam, guna melaksanakan bermacam-macam ibadah yang ada kaitannya dengan bulan qamariyah seperti shalat, puasa, haji dan hari-hari besar Islam lainnya. ${ }^{1}$ Benda-benda langit di alam semesta ini, termasuk langit dan bumi seluruhnya mempunyai tempat, manzilah-manzilah dan orbit yang tetap (konstan) tidak berubah dan pasti, sehingga apabila diamati dan diobservasi secara teliti dan cermat secara

${ }^{1}$ M. Yusuf Harun, Pengantar Ilmu Falak, (Banda Aceh: Yayasan PeNA, 2008), hal, 63.

berulang-ulang, maka akan dapat menghasilkan data yang konstan dan akurat. ${ }^{2}$

Di tengah umat Islam sering terjadi perbedaan dalam penentuan awal bulan kamariah pada gilirannya ini mengakibatkan perbedaan umat dalam mengawali puasa Ramadhan, beridul Fitri, dan beridul Adha. Perbedaan tersebut dapat terjadi dalam lingkup lokal, nasional, maupun Internasional, dan selisihnya kadang tidak hanya satu hari, bahkan dapat sampai tiga-empat hari. Perbedaan puasa Ramadhan dan Idul Fitri / Idul Adha sesungguhnya bukan sekedar fenomena ibadah ritual, melainkan

${ }^{2}$ Dhiauddin Tanjung dan Watni Marpaung, Ilmu Falak di Indonesia, (Medan: IAIN PRESS, 2013), hal, 51.

Penetapan Awal Bulan Dengan Metode Ittihadul Mathla' | 48 
juga fenomena syiar persatuan umat. Umat Islam yang sesungguhnya umat yang satu (ummatan wâhidah ) termasuk dalam hal mengawali puasa dan berhari raya- akhirnya nampak tercerai berai, terpecah belah, dan tidak kompak.

\section{Penetapan Awal Bulan Qamariyah}

Istilah bulan dalam bahasa Arab identik dengan kata al-syahr atau al-syuhrah yang juga berarti alqamar yaitu benda langit menjadi satelit bumi. Menurut Ibn Sayid, al-syahr (bulan) adalah satuan waktu tertentu yang sudah terkenal dari beberapa hari, yang dipopulerkan dengan bulan (al-qamar) karena qamar sebagai tanda memulai dan mengakhiri bulan. Dalam pengertian ini, bulan qamariyah berarti perhitungan bulan yang didasarkan pada sistem peredaran bulan (alqamar/lunar) mengelilingi bumi. ${ }^{3}$

Peredaran bumi, bulan dan matahari bersifat konstan, tetap, dan tidak berubah sebagai salah satu sunnatullah yang telah ditetapkan sejak Allah SWT menciptakannya. Peredaran ini tidak dalam pengertian tidak bergerak dan tidak mengalami perubahan, konstan, dalam pengertian senantiasa dalam bingkai ukuran-ukuran yang tidak berubahubah. ${ }^{4}$ Benda langit yang paling penting disini adalah matahari dan bulan. Dalam kaitannya dengan awal bulan yaitu saat matahari terbenam (ghurub alsyams), merupakan saat yang sangat penting, sebab pada saat itulah hilal awal bulan dapat dilihat dan pada saat ghurub itulah menurut hukum islam (syar'i) hari dan awal bulan dimulai. ${ }^{5}$

Fatwa MUI Tentang Penetapan Awal Ramadhan, Syawal, dan Dzulhijjah, Dewan Pimpinan Majelis Ulama Indonesia dalam Musyawarah Nasional II Tahun 1980. MEMUTUSKAN. Memfatwakan : (1) Mengenai penetapan awal Ramadhan dan Awal Syawal / Idul Fitri di kalangan fuqaha' terdapat dua aliran, yaitu pertama aliran yang berpegang pada mathla' (tempat terbitnya fajar clan terbenamnya matahari). Aliran ini ditokohi oleh Imam Syafi'i clan kedua aliran yang tidak perpegang ada mathla'

\footnotetext{
${ }^{3}$ Moh. Murtadho, Ilmu Falak Praktis. (Malang: UINMalang Press, 2008). hal, 216.

${ }^{4}$ Moh. Murtadho, Ilmu Falak, hal, 52.

${ }^{5}$ Moh. Murtadho, Ilmu Falak, hal, 55.
}

(jumhur fuqaha). Untuk mewujudkan ukhuwwah Islamiyah, Komisi Fatwa MUI mengambil kesimpulan agar dalam penetapan awal Ramadhan dan awal Syawal / Idul Fitri berpedoman pada pendapat jumhur, sehingga rakyat yang terjadi di suatu negara Islam dapat diberlakukan secara internasional (berlaku bagi negara-negara Islam yang lain).

Hal ini memerlukan kesempatan untuk membentuk lembaga yang berstatus sebagai "Qadi Internasional " yang dipatuhi oleh seluruh negaranegara Islam. Sebelum itu, berlakulah ketetapan pemerintah masing-masing. (2) Berbeda dengan masalah penetapan awal Ramadhan dan awal Syawal / Idul Fitri ialah masalah penetapan awal bulan Zulhijjah/Idul Adha. Dalam hal ini berlaku dengan mathla' masing-masing negara. Dalam hal ini ulama telah konsesus. Dengan demikian, Indonesia dalam melakukan shalat Idul Adha tidak dibenarkan mengikuti negara lain yang berbeda mathla'nya. ${ }^{6}$

\section{Dasar Hukum Penetapan Awal Bulan}

Pada al-Quran dalam surat Yunus ayat 5 dijelakan bahwa "dia-lah yang menjadikan matahari bersinar dan bulan bercahaya, dan ditetapkannya manzilah-manzilah (tempat-tempat) bagi perjalanan bulan itu, supaya kamu mengetahui bilangan tahun dan perhitungan (waktu). Allah tidak menciptakan yang demikian melainkan dengan hak. Dia menjelaskan tanda-tanda (kebesaran-Nya) kepada orang-orang yang mengetahui." (QS. Yunus: 5). ${ }^{7}$

Ayat al-Qur'an tersebut diatas menjelaskan bahwa matahari dan bulan beredar pada orbitnya (manzil)nya sehingga dapat dilakukan perhitungan waktu, bulan, dan tahun. Dari peredaran matahari dan peredaran bulan tersebut dikembangkan sistem kalender yang terkenal, yaitu kalender yang perhitungannya berdasarkan sistem perjalanan

${ }^{6}$ Majelis Ulama Indonesia, Keputusan Fatwa Majelis Ulama Indonesia Nomor 2 Tahun 2004 Tentang Penetapan Awal Ramadhan, Syawal, Dan Dzulhijjah, (Jakarta), http://rukyatulhilal.org. hal.3 (akses 07 juni 2017).

${ }^{7}$ Lajnah Pentashih Mushaf Departemen Agama RI, Al-Qur'an dan Terjemah, (Jakarta: PT. Dua Sukses Mandiri, 2012), hal. 209.

Penetapan Awal Bulan Dengan Metode Ittihadul Mathla’ | 49 
matahari yang dikenal dengan solar system, dan kalender yang berdasarkan pada perjalanan bulan yang disebut lunar system. Pada era sekarang ini, kalender yang terkenal bagi umat manusia dan berlaku secara universal adalah kalender Masehi yang menggunakan sistem perjalanan matahari dan kalender Hijriyah yang menggunakan sistem perjalanan bulan. ${ }^{8}$ Dalam sebuah hadits, Rasulullah SAW menyebutkan bahwa untuk menentukan awal masuk bulan baru yaitu dengan melihat hilal (ru'yatul hilal).

$$
\begin{aligned}
& \text { وَ عَنِ ابْنِ عُمَرَ رضى الله عنهما قال : سَمِعْتُ رَسُولَ اللهِ }
\end{aligned}
$$

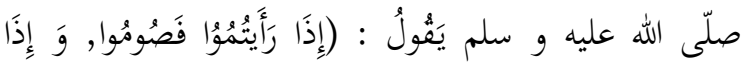

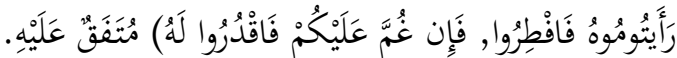

"Dan dari Ibnu Umar r.a berkata: aku mendengar Rasulullah saw bersabda: apabila engkau sekalian melihatnya (bulan) berupasalah, dan apabila engkau sekalian melihatnya (bulan) berbukalah, dan jika awan menutupi kalian maka kadarkanlah. (Muttafaq 'alaih). ${ }^{9}$

\section{Pemaknaan Ittihâdul Mathla'}

Ittihadul mathla' ialah persatuan tempat melihat hilal tanpa dibatasi oleh perbedaan geografis dan batas daerah kekuasaan. Kata mathla' secara bahasa berasal dari ta-la-'a yang artinya terbit, muncul, keluar. Kata ini kemudian dapat dibentuk menjadi mathli' dengan huruf lam yang dikasrah dan mathla' dengan huruf lam yang difathah yang memiliki makna yang berbeda. Kata bentukan pertama (mathli') bermakna tempat munculnya bulan, bintang, atau matahari sedangkan kata bentukan kedua (mathla') bermakna waktu atau zaman munculnya bulan, bintang, atau matahari. Makna ini dapat dilihat dalam al-Qur'an surat al-kahf ayat 90 dan QS Al-Qadr ayat 5.

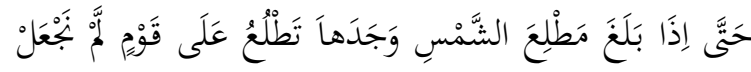

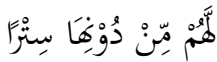

"Hingga ketika dia sampai di tempat terbit matahari (sebelah timur) didapatinya (matahari) bersinar di atas suatu kaum yang tidak Kami

\footnotetext{
${ }^{8}$ Moh. Murtadho, Ilmu Falak, hal, 91.

${ }^{9}$ Ibnu Hajar Al-'Asqalani, Bulughu Al-Maram Min Adilati Al-Ahkam (Indonesia: Haramain, TT), hal, 137.
}

buatkan suatu pelindung bagi mereka dari (cahaya matahari) itu".(QS. Al-Kahf: 90). ${ }^{10}$

Mathla' dalam istilah falak ialah luas daerah atau wilayah pemberlakuan hukum penetapan awal bulan qamariyah. Mathla' juga dapat disebut sebagai batas geografis keberlakuan rukyah.Ada tiga pendapat tentang mathla', yaitu : (a) Mathla' masâfatul qashri, yaitu batas keberlakuan wilayah sejauh 90 $\mathrm{km}$ (batas shalat qashar). (b) Mathla' wilayatul hukmi, yaitu pemberlakuan hukum ketetapan awal bulan untuk seluruh wilayah negara. (c) Mathla' global, yaitu pemberlakuan hukum ketetapan awal bulan berlaku untuk seluruh wilayah di permukaan bumi. ${ }^{11}$

\section{Penetapan Awal Bulan Qamariyah di Indonesia}

Indonesia menganut prinsip wilayatul hukmi, maka penanggalan qamariah harus sama di seluruh wilayah hukum republik Indonesia. Prinsip ini adalah salah satu dari tiga paham fiqh. Menurut Imam Hanafi dan Maliki, penanggalan qamariah harus sama di dalam satu wilayah hukum suatu negara. Sedangkan menurut Imam Hambali, kesamaan tanggal qamariah ini harus berlaku diseluruh dunia, di bagian bumi yang berada pada malam atau siang yang sama. Sementara itu, menurut Imam Syafi'i, penanggalan qamariah ini hanya berlaku di tempat-tempat yang berdekatan, sejauh jarak yang dinamakan mathla'. Inilah prinsip mathla' madzhab Syafi'i.

Indonesia menganut prinsip wilayatul hukmi, yaitu bahwa bila hilal terlihat di mana pun di wilayah kawasan Nusantara, di anggap berlaku di seluruh wilayah Indonesia. Konsekuensinya, meskipun wilayah kita dilewati oleh garis penanggalan Islam internasional yang secara teknis berarti bahwa wilayah Indonesia terbagi atas dua bagian yang mempunyai tanggal hijriah berbedapenduduk melaksanakan puasa secara serentak. ${ }^{12}$ Pada dasarnya cara atau sistem penetapan awal bulan qamariyah dapat diklasifikasikan ke dalam

${ }^{10}$ Lajnah Pentashih Mushaf Departemen Agama RI, Al-Qur'an, hal, 304.

${ }^{11}$ Moh.Murtadho, Ilmu Falak, hal, 50.

12 H.S. Farid Ruskanda, 100 Masalah Hisab Dan Rukyat: Telaah Syariah, Sains Dan Teknologi, Cet.1, (Jakarta: Gema Insani Press, 1996), hal, 18-19. 
dua sistem, yaitu sistem hisab dan sistem ru'yah. Sistem hisab maupun ru'yah mempunyai sasaran yang sama, yaitu hilal. Hal ini pernah dinyatakan oleh Mukti Ali sebagai Menteri Agama RI pada peantikan anggota Badan Hisab Ru'yah Departemen Agama tanggal 23 September 1972. Oleh karena itu, inti tujuan dari dilakukannya penentuan awal bulan baik melalui hisab atau ru'yah ialah mencari hilal. ${ }^{13}$

Rukyah berasal dari bahasa arab "ru'yah" yang artinya melihat. Hilal artinya yaitu bulan sabit. Rukyah yaitu melihat bulan sabit yang pertama terlihat setelah terjadinya ijtimak. Ijtimak terjadi saat posisi bulan dan matahari berada pada jarak yang paling dekat. ${ }^{14}$ Rukyah juga berarti kemampuan penglihatan normal untuk dapat melihat permulaan bulan Hijriah. Dalam menentukan bulan ini terdapat perselisihan ketentuan di kalangan para ahli; Pertama, Cahaya bulan ada seperlima inch (12 menit), dan busur Maktsul Hilal ada 3 derajat; kedua, Cahaya bulan ada dua pertiga inch (40 menit), dan Irtifa'nya ada 6 derajat; ketiga, Cahaya bulan ada dua pertiga inch, dan busur Maktsul Hilal ada 11 derajat. ${ }^{15}$

\section{Metode Ittihâdul Mathla' untuk Penentuan Awal Bulan di Indonesia}

Di dalam al-Qur'an, bulan disebut dengan tiga istilah, yakni syahrun, Qamar, dan hilal. Syahrun digunakan untuk menyebut bulan dalam arti durasi waktu yang berjumlah 29 atau 30 hari. Juga untuk menyebut nama bulan. Qamar digunakan untuk menunjuk sebuah benda langit yang menjadi satelit planet Bumi. Sebuah benda langit yang bercahaya dan selalu terlihat berubah-ubah bentuk seiring dengan pergerakannya mengelilingi Bumi. Sedangkan hilal adalah bulan yang pertama kali tampak cahayanya dari Bumi pada saat terbenam Matahari sesudah terjadinya ijtimak atau konjungsi.

Pada saat terbenam Matahari pada akhir bulan Sya'ban, Ramadhan, dan Zulkaidah, kedudukan bulan memang sudah positif terhadap ufuk dengan

\footnotetext{
${ }^{13}$ Moh. Murtadho, Ilmu Falak, hal, 220.

${ }^{14}$ Muchtar Yusuf, Ilmu Hisab dan Rukyah, ( Banda Aceh: Al-Washliyah University Press, 2010), hal, 9.

${ }^{15}$ Abdul Karim dan Rifa Jamaluddin Nasir, Mengenal Ilmu Falak, (Yogyakarta: Qudsi Media, 2012), hal, 20-21.
}

ketinggian setengah derajat untuk wilayah Indonesia paling Barat. Hanya saja, dari perspektif imkan rukyah manapun, ketinggian bulan sebesar itu belumlah memenuhi syarat untuk dapat melahirkan hilal. Artinya, bulan memang sudah berada di atas ufuk tetapi hilal belum lahir. Hilal inilah yang kemudian dijadikan sebagai penentu awal bulan hijriyah. Hilal hanya muncul satu kali dan selebihnya akan disebut qamar, dan seharusnya dalam batasan satu matla' hanya ada satu kali lebaran. Oleh karena itu, dalam hal penentuan awal bulan menggunakan metode rukyah yang ditandai dengan lahirnya hilal. Logikanya ketika ada satu hilal seharusnya hanya akan ada satu kebenaran penetapan dalam mengawali atau mengakhiri puasa dan lebaran.

Yang dimaksud dengan metode ittihâdul mathla' ialah persatuan tempat melihat hilal tanpa dibatasi oleh perbedaan geografis dan batas daerah kekuasaan. Ayat al-Qur'an maupun hadishadis yang dijadikan dasar hukum dalam penentuan awal bulan, telah memberikan informasi kepada kita bahwa "hilal" merupakan sesuatu yang menjadi landasan dalam perubahan waktu (masuknya bulan baru). Untuk mengetahui masuknya bulan baru dapat dilakukan observasi hilal dengan berdasarkan kepada mathla'. Terjadinya perbedaan dalam penetapan awal bulan juga dapat disebabkan oleh perbedaan mathla'.

Begitu banyak perbedaan tentang mathla', ada pendapat yang setuju menjadikan mathla' kedalam metode penyatuan mathla' dan ada pendapat yang tidak menyetujuinya berdasarkan alasan tertentu. Pendapat yang menyetujui hal ini mengemukakan pendapatnya bahwa dalam argumen sebuah hadits

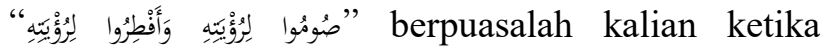
melihatnya (hilal) dan berbukalah ketika melihatnya. Argumen dari hadits ini dijadikan alasan oleh sebagian kelompok untuk mendasarkan bahwa kalimat shaumu (puasalah kalian) disini bermakna umum untuk siapa saja, oleh karena itu maka siapa saja yang melihat hilal, maka persaksiannya ini diterima dan dapat berlaku untuk seluruh umat muslim. 
Kewajiban dalam melaksanakan ibadah puasa tidak hanya diperintahkan setelah diutusnya Nabi Muhammad SAW., akan tetapi kewajiban tersebut telah ada jauh sebelum Nabi Muhammad SAW. diutus. Sebagaimana firman Allah SWT.

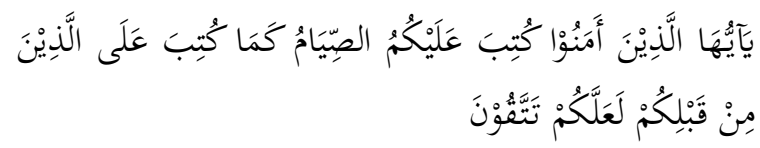

"Hai orang-orang yang beriman, diwajibkan atas kamu berpuasa sebagaimana diwajibkan atas orang-orang sebelum kamu agar kamu bertakwa." (QS. Al-Baqarah : 183) ${ }^{16}$

Sebagaimana penulis uraikan bahwa penentuan awal dan akhir Ramadhan merupakan masalah yang ramai diperbincangkan terutama setiap menjelang datangnya bulan Ramadhan dan menjelang Idul Fitri maupun Dzulhijjah. Perbedaan jatuhnya awal dan akhir Ramadhan tidak hanya disebabkan oleh adanya perbedaan antara kelompok hisab dan kelompok ru'yah saja, melainkan sering pula terjadi disebabkan adanya perbedaan kalangan yang berpegang pada ru'yah dan perbedaan kalangan yang berpegang pada hisab. Perbedaan intern kalangan yang berpegang pada ru'yah antara lain disebabkan dua hal. Salah satunya adalah karena adanya perbedaan tentang mathla'.

Pendapat ulama yang mengkaitkan dengan yurisdiksi kewilayahan atau terkenal dengan matla' menyatakan bahwa hasil rukyah di suatu tempat itu bisa berlaku untuk seluruh dunia. Pendapat ini menggunakan argumentasi bahwa dari hadis-hadis Nabi SAW yang berkaitan dengan rukyah, yang perintah puasa tersebut ditujukan kepada seluruh umat Islam di dunia dengan tidak membedakan letak geografis dan batas-batas daerah kekuasaan. Kelompok ini menggunakan mathla' global atau universal. Ulama lain berpendapat, bahwa hasil rukyah di suatu tempat mempunyai kewilayahan yurisdiksi keberlakuan yaitu hanya berlaku bagi suatu daerah, kekuasaan hakim yang menetapkan atau memberi keputusan atas hasil rukyah tersebut. Pendapat yang seperti ini terkenal dengan Rukyah fi al-wilayah al-hukmi (rukyah dalam kewilayahanya).

\footnotetext{
${ }^{16}$ Departemen Agama RI, Al-Hikmah Al-Qur'an Dan Terjemahnya (Bandung: CV Diponegoro, 2006), hal, 28.
}

Dasar hukum ru'yah lokal secara umum adalah hadits Nabi yang memerintahkan berpuasa bila melihat hilal dan berbuka atau berbuka atau beridul fitri bila melihat hilal. Sedangkan penampakan hilal bersifat lokal, tidak bisa secara seragam terlihat di seluruh dunia. Demi keseragaman hukum di suatu wilayah pemimpin umat bisa menyatakan kesaksian di manapun di wilayah itu berlaku untuk seluruh wilayah (konsep wilâyatul hukmi). Indonesia menganut prinsip wilayatul hukmi, dan mayoritas masyarakatnya bermazhab dengan madzhab Imam Syafi'i. Prinsip wilayatul hukmi ini maksudnya pemberlakuan hukum ketetapan awal bulan untuk seluruh wilayah Indonesia, namun masih saja ada perbedaan dalam penetapan awal bulan kamariyah khususnya penetapan Ramadhan, Syawal, dan Dzulhijjah. Hal ini tidak menutup kemungkinan untuk menerapkan metode penyatuan mathla' untuk melakukan rukyah hilal guna penetapan awal bulan qamariyah.

Indonesia merupakan salah satu wilayah yang dapat disebut dengan istilah wilâyatul hukmi karena Indonesia termasuk dalam 13 negara teritorial (wilayah) Asia Tenggara. Jadi, jika hilal dapat dirukyah di Indonesia dan beberapa negara-negara yang berada dalam teritorial yang sama, seperti Malaysia, Brunei, maka hal itu dapat mencakup negara-negara yang berada dalam teritorial yang sama untuk penentuan awal waktu masuk bulan baru. Bahkan ada juga pendapat yang hanya memberlakukan rukyah sebatas pada daerah yang dianggap memang memungkinkan adanya rukyah tersebut. Namun pendapat ini jarang sekali diikuti. Kita bisa mencoba memakai konsep yang di anggap lebih tepat dan sesuai dengan tuntutan keadaan yaitu memberlakukan mathla' wilayah al-hukmi pada suatu tempat dan waktu tertentu, dan sebaliknya memberlakukan mathla' global secara kondisional sesuai tuntutan kemaslahatan umat.

Secara ilmiah penggabungan antara hisab dan rukyah memang baik karena keduanya saling mendukung, tetapi kriteria yang ditetapkan sebesar 2 derajat tersebut sulit diterima masyarakat astronomi Internasional. Awal masuk waktu awal bulan itu 2 derajat di atas ufuk dan dapat dilihat dengan alat. Jika tidak dilihat dengan alat maka hilal itu tidak 
nampak, dan apabila masih -2 derajat hilal tidak memungkinkan dilihat walaupun dengan alat. Jika ada pendapat yang mengatakan posisi hilal 6 derajat di atas ufuk, maka itu bukan derajat awal bulan tetapi sudah memasuki hari kedua pada bulan tersebut, dan hal ini tidak memerlukan perhitungan terlebih dahulu seperti hitungan yang dilakukan pada posisi hilal 2 derajat di atas ufuk.

Berdasarkan data ru'yah di Indonesia sejak tahun 1960-an, ahli hisab di Indonesia pada awal 1990-an memformulasikan kriteria Imkan ar-Ru'yah menjadi ketinggian minimum hilal 2 derajat, jarak bulanmatahari minimum 3 derajat, atau umur hilal minimum 8 jam. Kriteria tersebut kemudian diterima di tingkat regional dan forum MABIMS (Menterimenteri Agama Brunei Darussalam, Indonesia, Malaysia, dan Singapura). Kriteria Depag RI berdasarkan tinggi hilal terendah yang dilaporkan bisa dirukyah, yaitu 2 derajat diatas ufuk mar'i. Kriteria ini berdasarkan ukuran tinggi hilal minimum 2 derajat menurut hisab dan digabungkan dengan hasil pengamatan (rukyah).

Selain itu, tempat paling strategis untuk melakukan rukyah yaitu berada di pinggir laut, ketinggian orang yang melakukan rukyah yaitu 3 meter diatas permukaan laut. Jika kita mengambil tempat di pegunungan, dikhawatirkan yang terlihat nanti bukan hilal, tetapi bayangan matahari. Sedangkan kriteria Konferensi Internasional 1978 di Istambul Turki, adalah tinggi hilal minimal 5 derajat dengan jarak bujur bulan dan matahari minimum 8 derajat. Penentu masuknya bulan baru penentuan awal bulan adalah terlihatnya hilal (bulan sabit) termuda di langit sebelah barat yang terjadi setelah adanya ijtimak (conjunction) antara matahari, bumi dan bulan, namun di lain sisi masih ada faktor lain yang menjadi penyebab tidak dapat seragamnya penentuan kalender Hijriyah di Indonesia ini. Di antara penyebab yang ada adalah pemahaman makna/definisi hilal yang tidak sama, ada yang mengatakan bahwa hilal adalah bulan sabit termuda yang dapat diru'yah/dilihat, dan ada juga yang mengatakan tidak harus dapat diru'yah/dilihat asalkan matahari sudah terbenam.

\section{Saksi Ru'yatul Hilal Menurut Imam Madzhab}

Mengingat bahwa perbuatan merukyah hilal ini merupakan salah satu fardhu kifayah. Apabila sebagian muslim ada orang yang sudah berusaha untuk rukyah al hilal, maka beban kewajiban bagi umat muslim lain secara keseluruhan sudah otomatis telah gugur, atau telah dianggap melakukan rukyah al hilal semuanya. Maka dari itu perukyah al hilal mestinya dilakukan oleh seseorang yang ahlinya dan professional membidangi ilmunya. Selain itu, syarat bagi seorang perukyah yaitu harus adil (bukan orang fasiq), laki-laki, islam, baligh, berakal, dan merdeka.

Mazhab Syafi'i menambahkan agar kesaksian tidak meragukan maka dibutuhkan dua orang lakilaki untuk kesaksian tersebut. Seorang perukyah harus 'adil, dan penilaian 'adil seseorang yang melihat hilal ini ada keterkaitanya dengan perhitungan hisab dimana rukyah itu dilakukan oleh orang yang adil terpercaya. Hal ini untuk mengantisipasi para perukyah yang di anggap kurang terpercaya sehigga mereka memberikan kesaksian palsu terhadap ru'yahul hilal. Dan dalam perspektif ini rukyah merupakan rangkaian kegiatan pembuktian dari hisab yang mana pada prinsipnya antara hisab dan rukyah tersebut keduanya saling melengkapi rukyah tidak dapat ditinggalkan salah satunya atau dipilh salah satunya.

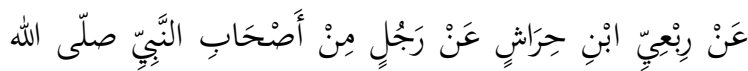

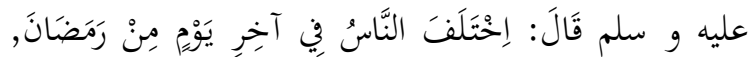

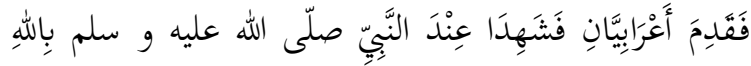

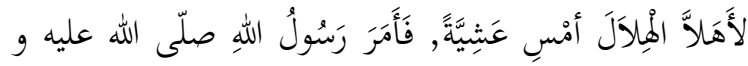

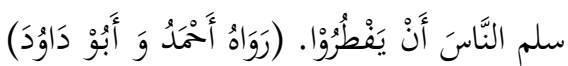

"Dari Rib'iy bin Hirasy, dari salah seorang sahabat Nabi SAW, ia berkata, "ketika orangorang berbeda pendapat mengenai hari akhir Ramadhan, tiba-tiba dua orang badui muncul lalu bersaksi di hadapan Nabi SAW bahwa keduanya melihat hilal kemarin sore. Maka Rasulullah SAW pun memerintahkan orang-orang untuk berbuka." (HR. Ahmad dan Abu Daud) $)^{17}$

\footnotetext{
${ }^{17}$ Alu Mubarak, Syaikh Faishal, Bin Abdul Aziz. Ringkasan Nailul Authar, Jilid. 2, Terj. Amir Hamzah Fachrudin, (Jakarta: Pustaka Azzam, 2006), hal. 338.
} 
Mengenai pendapat ulama tentang kesaksian dalam rukyah al-hilal ada beberapa asumsi tentang hal tersebut untuk itu apabila rukyah al-hilal tersebut digunakan untuk menentukan awal bulan Ramadhan, maka kesaksian seorang yang berkriteria adil yang berjumlah satu saja dapat diterima dan hal ini merupakan syarat seorang perukyah yang dalam perspektif ini seorang yang fasik secara otomatis dianggap tidak falid kesaksianya terhadap melihat hilal di saat awal bulan ramadhan. Kemudian apabila rukyah al-hilal dipakai untuk menentukan awal bulan Syawal (Idul Fitri), maka kesaksian yang hanya berasal dari seorang yang adil yang jumlahnya hanya satu belum bisa diterima. Yang dalam hal ini Setidaknya dibutuhkan saksi yang adil yang berjumlah dua orang minimal.

Menurut mazhab Syafi'i dalam menentukan penentuan awal bulan qamariyah khususnya penetapan awal Ramadhan, Syawal (Idul Fitri), dan Dzulhijjah (Idul Adha), ditetapkan berdasarkan pada kebiasaan masyarakat memegang ru'yahnya dari seorang yang adil walau identitas pribadinya tidak jelas, baik ketika langit dalam keadaan cerah atau tidak. Dengan syarat yang melihatnya termasuk orang yang adil, muslim, baligh, berakal, merdeka dan lelaki. Sebab Ibnu Umar pernah melihat hilal lalu menyampaikannya kepada Rasulullah saw., kemudian beliaupun menyambut beritanya dengan melakukan puasa dan memerintahkannya kepada masyarakat. Sedangkan Mazhab Hanafi, Maliki, dan Hanbali sepakat jika ada persatuan mathla' agar ummat tidak terpecah belah dalam penetuan awal bulan. Bahkan Rasulullah juga pernah melaksanakan puasa dimana pada saat itu Ibnu Umar yang melihat hilal.

$$
\begin{aligned}
& \text { عَنْ ابْنِ عُمَرَ, قَالَ: تَرَاءَى النَّاسُ الْمِلالَ فَأَخْبَرْتُ رَسُولُ اللهِ }
\end{aligned}
$$

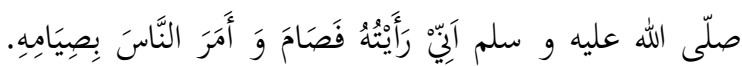

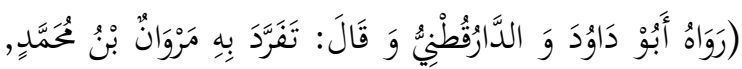

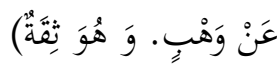

"Dari Ibnu Umar ia berkata, "ketika orang-orang sedang melihat-lihat munculnya bulan sabit (hilal Ramadhan), aku memberitahu Rasulullah SAW bahwa aku telah melihatnya, maka beliau pun berpuasa dan mmerintahkan orang-orang agar berpuasa pula." (HR. Abu Daud dan Ad-
Daraquthni, ia mengatakan, "Marwan bin Muhammad meriwayatkan sendirian dari Ibnu Wahb. Ia tsiqah $)^{18}$

Hal ini menunjukkan bahwa walaupun metode itttihâdul mathla' ini tidak ada dalam istilah rukyah, namun pada masa Rasul saw. sudah pernah terjadi walaupun hanya sekali. Jika dilakukan sebuah observasi tempat yang paling strategis, dan ketika merukyah hilal juga diperhitungkan dengan baik serta dilakukan oleh orang yang benar-benar ahli, maka dalam hal ini tidak menutup kemungkinan adanya persatuan mathla' untuk melakukan ru'yahul hilal.

Menurut mazhab Hanafi, perbedaan mathla' ini adalah zahir madzhab, dan merupakan pendapat mayoritas syekh, serta menjadi pegangan fatwa. Jadi, penduduk di daerah timur harus melaksanakan puasa jika penduduk di daerah barat telah melihat hilal. Hal ini berlaku jika penduduk timur telah mengetahui hal itu secara pasti, misalnya dengan ada dua orang yang melaporkan kesaksian penduduk di daerah barat kepada mereka, atau ada dua orang yang bersaksi telah melihat keputusan hakim di daerah barat, atau beritanya telah tersebar luas

Menurut madzhab Maliki, apabila hilal telah terlihat, puasa wajib dilaksanakan di semua negeri, baik yang letaknya dekat maupun jauh. Jarak shalat qashar tidak masuk hitungan, begitu pula kesamaan maupun perbedaan mathla'. Jadi, puasa wajib dilaksanakan oleh setiap orang yang menerima berita kemunculan hilal tersebut. Hal ini berlaku jika kemunculan hilal itu terbukti dengan kesaksian dua orang yang berbudi luhur atau penuturan orang banyak. Menurut madzhab Hambali, apabila hilal terlihat di suatu tempat,baik itu dekat ataupun jauh, maka semua orang harus berpuasa, dan orang yang tidak melihat hilal itu sama hukumnya dengan orang yang telah melihatnya.

Dikaitkannya puasa dengan melihat hilal telah dijadikan pegangan oleh mereka yang berpendapat bahwa penduduk suatu negeri wajib melaksanakan puasa apabila penduduk negeri yang lain telah melihatnya (hilal). Jumhur ulama madzhab yang

\footnotetext{
${ }^{18}$ Syaikh Faishal, Bin Abdul Aziz Alu Mubarak, Ringkasan, hal, 337.
}

Penetapan Awal Bulan Dengan Metode Ittihadul Mathla' | 54 
tidak membatasi mathla' dalam hal penentuan awal bulan qamariyah ini memiliki alasan dan dalil yang dapat dipertimbangkan kembali. Alasannya dapat dilihat dari beberapa hal yaitu jika hilal terlihat di suatu tempat, maka tempat lainnya yang tidak atau belum melihat hilal dapat mengikuti tempat yang telah melihat hilal. Dan kemunculan hilal tersebut terbukti dengan kesaksian dua orang yang berbudi luhur atau berdasarkan penuturan dari orang banyak yang tidak mungkin berdusta. Selain itu, kabar tentang terlihatnya hilal disuatu tempat juga harus benar-benar akurat dan pasti, dan kabar tersebut bukan kabar yang dibuat-buat (kabar dusta). Jumhur ulama mazhab Hanafi, Maliki dan Hanbali beragumen tentang dibolehkannya penyatuan mathla' dengan dua alasan. Pertama mereka beralasan dengan Hadits Abu Hurairah:

$$
\begin{aligned}
& \text { عَنْ أَبِيْ هُرَيْرَة قَالَ: قَالَ رَسُوْلُ اللهِ صلّى الله عليه و سلم : }
\end{aligned}
$$

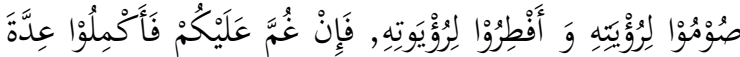

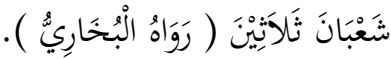

"Dari Abu Hurairah, ia berkata, Rasulullah saw bersabda, berpuasalah kalian karena melihatnya (yakni hilal Ramadhan) dan berbukalah kalian karena melihatnya (yakni hilal Syawal). Jika tidak terlihat oleh kalian (karena tersembunyinya hilal) maka sempurnakan hitungan Sya'ban hingga tiga puluh (hari)". (H.R. Al-Bukhari) ${ }^{19}$

Hal ini menunjukkan bahwa kewajiban puasa atas kaum Muslimin itu bergantung pada ru'yah secara muthlak, dan perintah yang muthlak itu berlaku sesuai dengan kemutlakannya. Maka dari itu, ru'yah sekelompok orang atau satu orang yang dapat diterima kesaksiannya terhitung cukup. Menjadikan hadits ini sebagai dalil berlakunya ru'yah penduduk suatu negeri atas penduduk negerinegeri lain lebih zahir daripada menjadikannya sebagai dalil atas tidak berlakunya hal tersebut. Sebab apabila hilal telah terlihat oleh penduduk suatu negeri, berarti ia telah terlihat oleh kaum muslimin. Maka, kewajiban puasa yang harus mereka laksanakan juga harus dilaksanakan oleh kaum muslimin di negeri-negeri lain.

\footnotetext{
${ }^{19}$ Syaikh Faishal, Bin Abdul Aziz Alu Mubarak, Ringkasan, hal. 342-343.
}

Para imam mazhab sepakat bahwa awal Ramadhan dan Syawal ditetapkan berdasarkan ru'yatul hilal atau istikmal. Ru'yah artinya melihat. Melihat hilal dengan menggunakan alat seperti teropong. Sebelum melakukan ru'yah, terlebih dahulu harus di hitung deklinasi, posisi bulan, jam busur dan transit matahari. Kemudian setelah dihitung data-data yang diperlukan untuk rukyah, maka rukyah dapat dilakukan dengan alat untuk melihat hilalnya. Hukum rukyah yaitu fardhu kifayah, dan waktu untuk melaksanakan rukyah pada akhir bulan Sya'ban atau Ramadhan. Rukyah baru diterima jika memenuhi beberapa syarat, yaitu: pelaku rukyah itu adil dalam persaksiannya, dan ketika pelaku rukyah menyampaikan persaksiannnya harus di dampingi oleh dua orang saksi yang adil pula.

Fuqaha berselisih pendapat tentang jumlah bilangan saksi yang memungkinkan diterimanya persaksian ru'yah mereka. Imam Abu Hanifah berpendapat bahwa apabila langit cerah, maka untuk menetapkan awal bulan Hijriah dengan persaksiannya orang banyak. Tetapi jika langit tertutup awan, maka persaksian seorang lelaki dapat diterima. Imam malik berpendapar, tidak boleh berpuasa atau berhari raya dengan persaksian kurang dari dua orang yang adil. Sedangkan imam Syafi'i dan Hambali berpendapat bahwasannya boleh memulai puasa berdasarkan persaksian rukyah seorang lelaki, tetapi tidak boleh berhari raya Idul Fitri berdasarkan persaksian kurang dari dua orang laki-laki.

Ada satu pertimbangan lagi yang sangat penting yaitu persatuan dari umat islam sendiri. Apabila hukum rukyah diberlakukan secara lokal, maka hal tersebut memancing perpecahan. Jumhur fuqaha mengatakan rukyah di suatu negara berlaku juga bagi negara-negara lain di dunia (bersifat global). Didalam madzhab Syafi'i ada lima pendapat tentang jarak garis batas mathla' dari lokasi ru'yahul hilal, yaitu: pemberlakuan hasil rukyah hanya sejauh jarak dimana qashar shalat di izinkan, yaitu kira-kira $80 \mathrm{~km}$, pemberlakuan hasil rukyah sejauh 8 derajat bujur, pemberlakuan hasil rukyah senegara (wilayatul hukmi) seperti Indonesia, pemberlakuan hasil rukyah sejauh 24 farsakh $(133 \mathrm{~km})$, dan 
pemberlakuan hasil rukyah hilal berlaku bagi daerah yang jauh dan daerah tersebut keadaan hilalnya masih mungkin untuk dirukyah, namun jika daerah yang jauh dan tidak memungkinkan untuk dirukyah maka hasil rukyah daerah lain tidak berlaku bagi daerah yang tidak imkanurrukyah tersebut.

Ibadah puasa dan perayaan 1 Syawal yang dilaksanakan oleh seluruh umat muslim dapat dilakukan secara serentak dan kompak. Hal ini dapat mencegah timbulnya perselisihan dan perpecahan antar umat islam dalam penentuan awal bulan qamariyah khususnya Ramadhan, Syawal dan Dzulhijjah, juga agar kewajiban puasa dapat disandarkan pada ru'yah tanpa adanya diskriminasi antara satu tempat dengan tempat yang lainnya. Islam adalah agama untuk seluruh dunia. Kesatuan adalah simbol Islam, dimana dalam Al-qur' an surah Al-Mu'minun disebutkan bahwa umat Islam adalah umat yang satu.

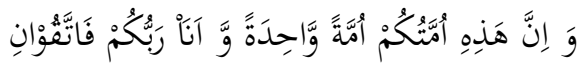

"Dan sungguh, (agama tauhid) inilah agama kamu, agama yang satu, dan Aku adalah Tuhanmu, maka bertakwalah kepada-Ku." (QS. Al- Mu'minun: 52). ${ }^{20}$

\section{Penutup}

Untuk menentukan masuknya bulan hijriah, khususnya bulan Ramadhan, Syawal dan Dzulhijjah dapat dilakukan dengan salah satu dari 3 cara, yaitu: melihat hilal (ru'yatul hilal), menyempurnakan bulan (istikmal), dan mentakdirkan adanya hilal dengan ilmu hisab. Cara tersebut saling berkaitan dengan hilal sebagai kunci utama masuknya bulan baru. hilal terlihat di suatu tempat, maka tempat lainnya yang tidak atau belum melihat hilal dapat mengikuti tempat yang telah melihat hilal. Dan kemunculan hilal tersebut terbukti dengan kesaksian dua orang yang 'adil atau berdasarkan penuturan dari orang banyak yang tidak mungkin berdusta.

Indonesia merupakan salah satu wilayah yang dapat disebut dengan istilah wilayatul hukmi karena Indonesia termasuk dalam 13 negara teritorial (wilayah) Asia Tenggara. Jika hilal dapat diru'yah pada beberapa negara dalam wilayah Asia Tenggara, maka negara dalam wilayah tersebut dapat mengikuti wilayah lain yang telah melakukan ru'yah. Dalam artian, bahwa negara tersebut masih dalam kawasan wilayah Asia Tenggara. Metode Ittihadul mathla' ini bertujuan untuk mempersatukan negara muslim agar dapat bersama melakukan ibadah puasa Ramadhan, dan melaksanakan shalat Idul Fitri secara serentak.

\section{DAFTAR PUSTAKA}

Al Asqalani, Ibnu Hajar. Bulughu Al-Maram Min Adilati Al-Ahkam. (Indonesia: Haramain. TT).

Alu Mubarak, Syaikh Faishal Bin Abdul Aziz. Ringkasan Nailul Authar, Jilid. 2, Terj. Amir Hamzah Fachrudin. (Jakarta: Pustaka Azzam. 2006)

Departemen Agama RI. Al-Hikmah Al-Qur'an Dan Terjemahnya. (Bandung: CV Diponegoro. 2006)

Harun, M. Yusuf. Pengantar Ilmu Falak. (Banda Aceh: Yayasan PeNA. 2008)

Karim, Abdul dan Rifa Jamaluddin Nasir, Mengenal Ilmu Falak. (Yogyakarta: Qudsi Media. 2012)

Lajnah Pentashih Mushaf Departemen Agama RI, Al-Qur'an dan Terjemah. (Jakarta: PT. Dua Sukses Mandiri. 2012)

Majelis Ulama Indonesia. Keputusan Fatwa Majelis Ulama Indonesia Nomor 2 Tahun 2004 Tentang Penetapan Awal Ramadhan, Syawal, Dan Dzulhijjah. (Jakarta) http://ru'yahulhilal.org. (akses 07 juni 2017)

Murtadho, Moh. Ilmu Falak Praktis. (Malang: UINMalang Press. 2008)

Ruskanda, H.S. Farid. 100 Masalah Hisab Dan Ru'yah: Telaah Syariah, Sains Dan Teknologi. Cet.1. (Jakarta: Gema Insani Press. 1996)

Tanjung, Dhiauddin dan Watni Marpaung. Ilmu Falak di Indonesia. (Medan: IAIN PRESS. 2013)

Yusuf, Muchtar. Ilmu Hisab dan Rukyah. (Banda Aceh: Al-Washliyah University Press. 2010). 345 .

\footnotetext{
${ }^{20}$ Departemen Agama RI, Al-Hikmah Al-Qur'an, hal.
} 